\title{
UNOCHA MISSION
}

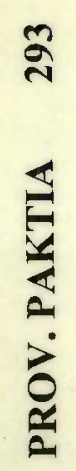

Objectives:

- To visit women and homeschool projects in Taliban area.

- To attend ACBAR Southeast Coordination Meeting in Khost.

\section{Related issues:}

\& Taliban, women, education, income generation, health, repatriation, water, irrigation, agriculture, shelter, demining, disability, roads, deforestation.

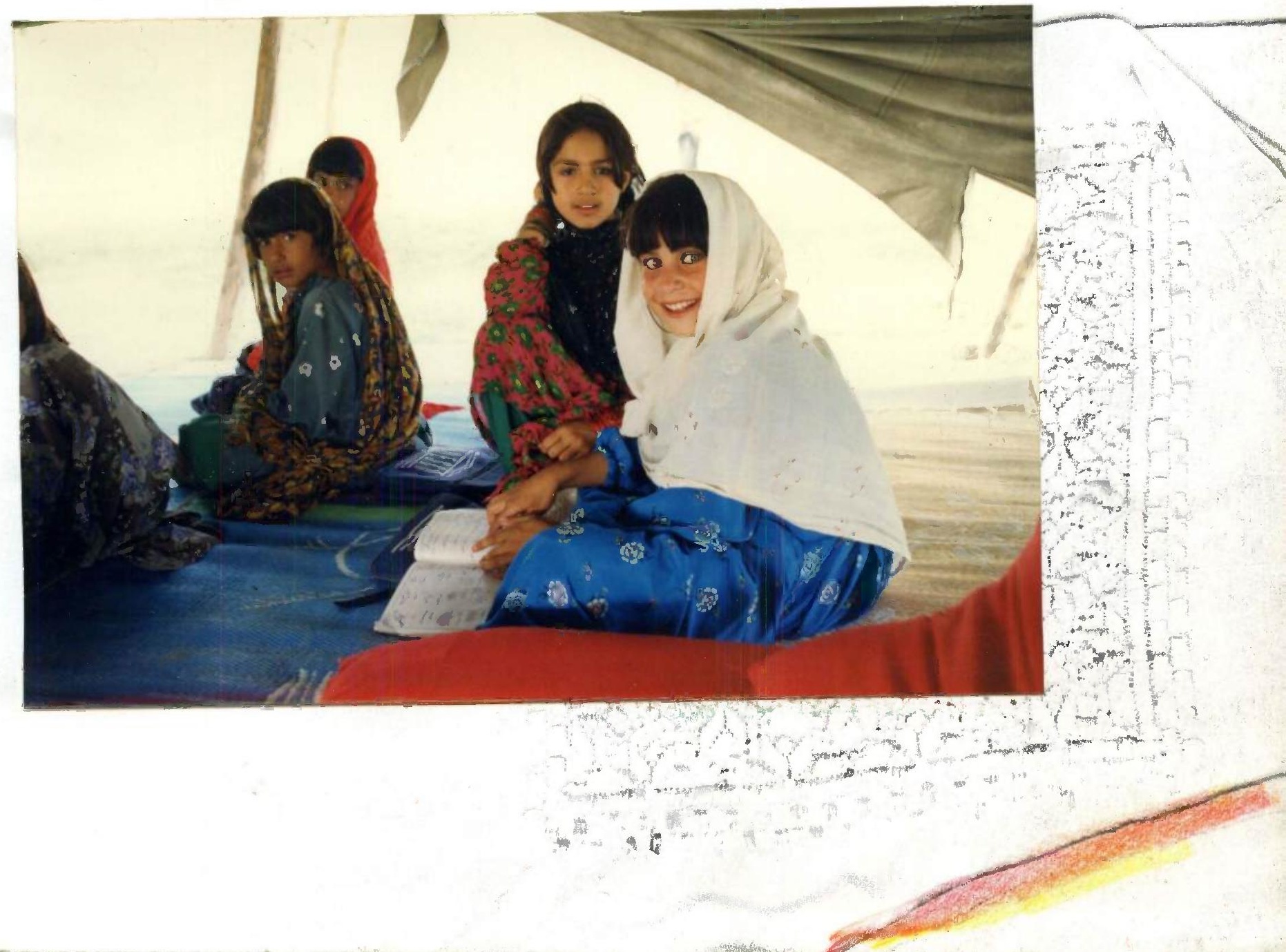




\title{
UNOCHA MISSION
}

\section{GARDEZ - KHOST, PAKTIA PROVINCE, EASTERN AFGHANISTAN,}

\author{
21 - 24 JULY 1997
}

\section{REPORT}

\section{Objectives:}

- To visit women income generation projects near Gardez and learn about implementation conditions.

- To attend the ACBAR Southeast Coordination meeting in Khost on 22 July.

- To visit a homeschool project in Khost.

\section{Summary of findings:}

Paktia province (with Khost area) is considered to be "liberal" minded towards women's and homeschool projects. As a result income generation projects for needy women (mostly widows) and homeschool projects for girls and boys are being implemented and indirectly supported by local Taliban authorities. There are many needy village women who desperately need assistance in the field of income generation and female health care. The best way to target these women is through small scale and low profile community based projects. Several NGOs (international and national) have gained sufficient expertise in implementing such projects and are ready to expand their activities. Female national NGO staff are facing no difficulties with Taliban authorities. They are well respected within the community and familiar with problems of target beneficiaries. There seems to be a need for a regional female coordinator for women's affairs. No international female staff is working in Paktia province.

\section{Recommendations:}

- To continue and expand regional income generation projects for women.

- To install female health care facilities in villages.

- To continue and expand regional homeschool projects.

- To provide office management training to regional women NGOs in order to enhance performance and accountability. 


\section{Itinerary:}

Monday, 21 July: AM: Arrival of OIC from Peshawar in Gardez by air; welcome by Mr. Kwabena Asante, UNOCHA Gardez; briefing at UNOCHA. PM: Visit to NPO/RRAA income generation projects for women in Zormat district; meeting with a refugee return family and a Kochi family near Gardez; participants in road mission: two female and one male national NPO/RRAA project staff, OIC. After return to Gardez city: visit to ARC reforestation project Terra Gardens in Gardez (Mr. Asante, OIC).

Tuesday, 22 July: AM: Departure to Khost city; participants in road mission: Mr. Asante, OIC, Mr. Karim (driver); attendance of ACBAR South East Coordination meeting in Khost. PM: Visit to CARE homeschool project in Khost city; visit to airport and bazaar; overnight stay at FAO Khost.

Wednesday, 23 July: AM: Departure to Gardez city by road. PM: Visit to Gardez timber and carpentry market (Mr. Karim, OIC); briefing with CARE (OIC) and meeting with AMRAN (Mr. Asante, OIC), both in Gardez city.

Thursday, 24 July: AM: Visit to Gardez civil hospital (Mr. Asante, OIC), departure to Peshawar by air.

\section{VISITING PROGRAMME:}

\section{Visit to NPO/RRAA women's projects in Zormat district, Paktia province.}

NPO/RRAA started its women programme in Paktia and Paktika province in 1993. A total of 452 widows and poor women have been assisted during since then by providing them with different income generating skills. In 1996 needy women (widows and poor women) in Zormat district received training in following skills: poultry (14 women), tailoring (46), animal husbandry (74), beads making (32), midwife training (11) and embroidery (9).

NPO/RRAA arranged in Zormat district group meetings with target women and individual visits to female headed households in two villages (Liwan and Alei Khanwal). During the visit women showed their production of bead work and parts of embroidery for local dresses (sleeves and frontpieces), skills which were taught to them during the training course. Bead work and embroidery products find sufficient buyers in the local market since both skills are part of female handicraft tradition. One women showed goats and chicken as received during animal husbandry training. Visited village women were very poor. A clear indicator of the level of poverty was the absence of tea during visits. Tea is traditionally served to guests in Afghan private homes. In this case tea and sugar have become luxury goods which poor households cannot afford anymore to buy. There were no Taliban present in the villages visited and female national project staff move around without difficulties and discussed problems with male village elders. One household meeting was attended together by male and female NGO project staff. The general impression was that national female project staff show great familiarity with project sites and are well respected within communities. 
Women's needs: Village women described their needs as follows: need for income generation due to poverty, need for mother-child health care facilities (no treatment facilities are existing in villages, no medicine is available in villages and public transport to Gardez city does not exist) and need for literacy training. It was reported that ongoing training courses are well attended and women are keen to learn. Women are actually asking for more courses and additional embroidery material. At Liwan village, a midwife training course has been completed and women explained their need for a village based MCH clinic. (The only regional hospital is in Gardez city and cannot be approached by most women due to lack of public transport.) At Alei Khanwal village a 16 year old girl, who has completed an embroidery course, is going to teach other women in this skill in combination with literacy training.

Villagers' needs: At Liwan village a separate meeting with village elders was arranged who expressed their need for irrigation schemes, provision of pesticides and mine clearance activities. (One can see red marked stones besides the road on the way to Liwan village, signaling mined areas.)

\section{Meeting with a refugee return family:}

UNHCR is currently undertaking a needs assessment survey among returning refugee families in Gardez, Paktia province. The objective of the survey is to compile a list of essential needs for returnees and to carry them out as regional quick impact projects. Priority needs are access to water (both drinking water and irrigation), shelter and demining. - A refugee return family was visited on the way back to Gardez city. The returning family arrived from Pakistan four days ago and was in the process of rebuilding their home. The family property consisted of crumbled mud walls surrounding an empty court yard. The family belongings were spread out on rugs under few poplar trees outside the wall. Male family members have begun to build a small room inside the wall and beams for a roof have already been laid. But there is no water available and the family's father showed a well filled up with dirt. The family does not have money to pay for cleaning of the well. Asked if their property has been cleared of landmines, the male head said he has no idea. Before returning to Afghanistan the family has received UNHCR plastic sheeting and wheat but no cash as other returning families did. Asked how, under such harsh conditions, the family managed to survive, the men said: "Well, at least we have got our weather back." (Afghanistan has pleasant summer months compared to Pakistan's heat and humidity.) The family was given the address of UNOCHA Gardez to contact there UNHCR.

\section{Meeting with a Kochi family:}

Like little black dots all over the Gardez highlands Kochi, the nomads, tents are pitched everywhere in the open and grasing herds of camels, sheep and goats can be seen. During hot summer months Kochis live in cooler highlands from where they start migrate to lower grasing lands in autumn. The family we visited comprised 50 members in three tents and camped close to Gardez city. Three male elders and one elderly women were present in the guesttent. Tea was served and in the following exchange of thoughts, Kochi elders showed to be well informed about ongoing events in Afghanistan and expressed their wish for peace. Asked if landmines affect Kochi migration, the elders said yes. They have already lost animals and some time ago a family members became a victim as well. A Kochi elder pointed towards the end of the valley where, according to their knowledge, demining teams have marked areas as mined. 


\section{Visit to Terra Gardens:}

Terra Gardens is a fruittree reforestation project funded by WFP and implemented by ARC. The gardens are close to Gardez city and provide a public recreation area. One can walk through rows of various fruittrees and pick fruits free of charge. At the moment deliciously tasting apricots are in season. The majority of visitors to the gardens comes from nearby regional demining offices who enjoy an evening walk after work.

\section{ACBAR South East Coordination Meeting in Khost, 22 July 1997:}

The meeting was held at CARE office and attended by 30 representatives of UN agencies (FAO, UNOCHA), ACBAR (Mr. Javed Ludin), NGOs (among others CARE, DACAAR, IRC, Shelter Now, HCI) and regional Taliban authorities (Dept. of Foreign Relations, Khost; Dept. of Disability, Khost; Dept. of Reconstruction, Gardez).

The Director of the Dept. of Foreign Relations (DFR), Khost, welcomed participants and expressed the need for peace and security in Afghanistan. There is further a need for reconstruction, in particular in the field of education and agriculture, and a great need for assistance to returnees. - The Director of the Dept. of Rehabilitation, Gardez, gave initially a brief outline of Afghanistan's recent history. (Continuous foreign interference since successful resistance against Russian occupation, and based on this, the Taliban's need to fight against it). Ongoing conflict prevents reconstruction of Afghanistan but there are many areas which enjoy complete security such as southeast Afghanistan. There are two major problems in Paktia province. One is repatriation of refugees. Returnees need urgent assistance in rebuilding their destroyed homes. In addition they have no access to drinking water and irrigation systems are destroyed. Secondly, agricultural infrastructure, clinics and schools need to be rebuilt. Thirdly, the population suffers of serious economic problems and need assistance in this regard. - The Director of the Dept. of Disabled, Khost, thanked the international community for assistance and stressed the importance of security as basis for rehabilitation. He informed that Khost province has 7,000 disabled persons and 45,000 orphans, all of them in need of assistance. Humanitarian assistance to these needy people would be highly appreciated.

In a second part, UN agencies were invited to report on activities. UNOCHA informed about repatriation activities in Gardez (UNHCR needs assessment among returnees, identified priority areas: water, irrigation, shelter.) UNOCHA further explained the nature of humanitarian assistance (assistance does not mean taking over local responsibilities) and stressed the importance of female education. The Director of DFR responded directly to this question by pointing out that boys and girls are attending homeschools in Khost. Further UNOCHA mentioned the problem of deforestation and stated that donor visits would help attracting attention to the problems of the region. UNOCHA also reminded NGOs to report to local authorities if projects have not been approved by donors. - FAO informed about its regional livestock (involving 50 fieldunits) and animal vaccination programme. The animal vaccination programme is in a process of becoming selfsustainable through costrecovery. In addition FAO has introduced a new kind of highquality nutrition for animals (molasses) which contributes to improved animal health. FAO intends to expand its programme. 
Reports from other agencies and a general discussion followed. The mine problem was mentioned for instance and the need for more assistance to the region mentioned. - During the discussion the Director of DFR asked why UN agencies do not return to Peshawar, Kandahar and Jalalabad, areas which are peaceful and with sufficient infrastructure. (Sic! He was not asking for a return of the UN to Kabul.) He inquired further about the status of a rehabilitation project regarding water supply to Khost city. The project was submitted to UN agencies but no response has been received yet. Finally the Director of DFR draw attention to the destroyed Laka Tiga bridge, half way between Gardez and Khost, which needs repair. - CARE stated that many areas in the region have passed the state of emergency assistance and are now in need of development support. This is particular true for agriculture and rehabilitation of the local economy.- HCI mentioned that they are carrying out projects in the field of vocational training and disability. - DACAAR informed about a research project on increased yields and a missing roller, which the Director of DFR promised to hand back. - Regarding improved communication between the region and Peshawar it was agreed to consider the idea of a regular pouch system. FAO could facilitate communication through radio contact.

A subsequent UN/NGO meeting with the Governor of Khost was conducted shortly afterwards. (Upon request the OIC did not attend this meeting.) The Governor was briefed on the outcome of the ACBAR meeting and raised in addition following issues:

- The damaged Laka Tiga bridge on the way between Khost and Gardez needs repair.

- Water supply to Khost city and neighboring areas need to be rehabilitated.

- High number of registered NGOs (approximately 60) without implementing activities.

- Decreased activities of CARE and DACAAR in the region.

- Absence of a medical NGO working in Khost civil hospital.

\section{Visit to CARE home school project in Khost city:}

CARE, with support of UNICEF and Canadafund, is currently implementing a pilot project for 39 community based homeschools with a total of 1,400 students in Khost area. The mission visited a homeschool which is located in a tent in front of an Afghan family compound outside Khost city. 33 girls and 12 boys attend the class normally which is conducted by a female and a male teacher who live in the nearby compound. Children are thought Mathematics, Pashto and Islamic studies. The textbooks they use are produced by GTZ BEFARe, originally meant for Afghan refugee children in Pakistan. Calculations are for instance carried out in Pakistan Rupees (PRS). Each homeschool is administered by a committee comprising one local elder and two educationalists who decide on curricula and conduct of teaching. Parents pay for each child 20 PRS schoolfees. The classroom is made of a big military tent, contains one blackboard, a teacher's desk and chair and mates on the ground on which children sit. During winter classes are given indoor. Classes are usually held at a time when children are not busy with other family duties such as collecting water or tending cows. During the hot season classes are conducted in the late afternoon. The one we visited was an ad hoc arrangement in the early afternoon but kids seemed not to mind and eagerly presented reading and calculating skills. (At some stage children simply could not refrain from examining the OIC's pair of glasses, a strange thing they have never before seen in their life.) 
It was explained that Khost has always been a traditional center for learning. That is why the homeschool project was encouraged by Taliban authorities. (The Director of the Dept. of Foreign Relations invited mission members during the ACBAR meeting to visit a local homeschool.) Regarding the relationship between project staff and Taliban authorities, a CARE national staff replied:"We know who we are and who are they." Relationships are good, was explained. But to be cautious the homeschool committee employed a female and a male teacher together, in case Taliban authorities start object against female teachers. CARE intends to expand the homeschool project to the neighbouring provinces of Paktika, Logar and Ghazni.

\section{Meeting with CARE in Gardez:}

The purpose of the meeting was to be briefed on CARE's regional programme SoFAR (Security of Food for Afghan Refugees) and learn about evaluation steps involved. The Provincial Administrator explained that a problem analyses had been carried out in Paktia province. It showed that low agricultural production, poor access to markets and environmental degradation are main causes for household food and livelihood insecurity. Based on these findings, CARE decided to undertake activities in the field of road repair, water, irrigation, flood protection and tree planting. The programme targets 96 villages. Target districts and communities have been selected on basis of a multiple factor analyses taking into account among others accessibility, landmines, security and community organization. CARE is planning to employ national female teams.

\section{Meeting with AMRAN in Gardez:}

AMRAN is a national NGO which carried out a WFP funded umbrella income generation project for needy women in Gardez. The umbrella structure involved among others several local women NGOs. The project targeted 560 women and ended in June. WFP decided not to continue supporting the project. During the meeting UNOCHA explained reasons for this decision. AMRAN did not show accountability as required from a serious UN implementing partner. Project documentation for instance is still missing. It was agreed that a communication gap between the NGO's headoffice and the field might have played a role as well. AMRAN argued further that enhanced dialogue between UN agencies and national NGOs would contribute to an improved relationship between both. In addition UN agencies should give more time explaining implementation rules and procedures. UNOCHA on the other hand pointed out that many national NGOs are in fact contractors and not really interested in partnership. Victims of such failed project cooperation are people, in this case needy women. UNOCHA further stated that providing national NGOs with office management training could help improving performance and accountability. Afghan women NGOs are in particular in need of such training. Women NGOs are very dedicated but never really had a chance to acquaint themselves with international office procedures.

\section{Visit to Gardez civil hospital:}

Gardez civil hospital is the only civilian hospital facility in Gardez area. It has a capacity of 150 beds with an internal patient department (IPD) newly opened. Originally it was thought that MSF would provide training to hospital staff (male and female) but as the situation looks at the moment MSF is not going to be involved.- A short visit to the hospital revealed armed Taliban 
guarding the entrance to the IPD wing where a young severed Talib, just brought back from Kabul frontline, was lying in bed with his right leg amputated under his knee. The Talib said it happened through a landmine. The freshly amputated stump was only scarcely covered with bandage and bloodstains were visible on bedsheets, floor and even outside in the aisle.- In front of the outdoor patients department, on the other side of the hospital, Afghan women were waiting for their children to be treated. Some of the women had walked two, three hours from their villages to the hospital. One mother kept a baby which showed signs of malnourishment. The infant's face looked like as if skin had been wrapped around a skull. The mother was desperate, explaining that her baby was not accepting its mother's milk and that the baby was constantly vomiting and she did not know what to do. Other women were waiting with their children to be vaccinated.

\section{Proposed meeting with the Deputy Governor in Gardex:}

Despite several attempts it was not possible to arrange a meeting with the Deputy Governor of Paktia province.

\section{General observations:}

- In villages visited only old people, women and children were present. It was explained that young and middle aged men were trying to find work in Iran and Pakistan.

- Harvest season was full in swing. Everywhere one could see people cutting corn. Rice fields showed a rich deep green.

- One third of the road between Gardez and Khost is in an appalling condition and travelling by road in the region is very exhausting. (Tarred roads are hardly existing.).

- Only very few trucks and minibuses and hardly any private cars are in use. People are forced to walk long distances. The few horses seen were used as packhorses.

- Kochi tents are like black dots painted all over Gardez highlands and shepherds tend flocks of sheep and goats and camels.

- DACAAR reconstructed wells are in use everywhere

- A newly finished UNHCR funded clinic half way between Khost and Gardez is occupied by Taliban militia. The building itself is empty with young Taliban squatting in four rooms. Two tanks and several guns are positioned in front of the clinic. In the nearby teahouse young local men including a beardless Talib did not object being photographed.

- The Talib official, who travelled with us from Gardez to Khost in order to attend the ACBAR meetingl, had no objections sharing the same car with an international female staff.

- Between Gardez and Khost (a five hours drive) there is hardly any village visible which does not show signs of depopulation and destruction. Most of the villages look empty with only few houses partly rebuilt. The amount of physical destruction in Gardez and Khost city is beyond imagination. The private residence of the Deputy Governor of Paktia province in Gardez city, for instance, is a former school building. It shows a makeshift roof, has neither window frames nor glass. Inside there are broken stairs and doorframes are not existing. The Deputy Governor lives in a room on the first floor, is the only room with a door.

- A villager in Zormat district showed a three meter long Russian bomb shell laying in his garden.

- In the morning young boys are seen making their ways to village madrasas. 
- The women meeting in the village was like a look back into a very ancient and archaic world. Attending women had tattooes on forehead, chin and hands and this look of endured austerity, but a warm welcoming smile and hands were shaken with all of them. They were so poor, they could not offer tea to the guest.

- Volleyball and Football seem presently be the favorite game of male residents in Gardez city. - Women are hardly visible in the bazaar of Gardez and Khost but are the more present in villages. Village women do not wear burqa . A male villager: "You see Taliban have no influence here."

- Village women asked if they have heard about the BBC educational soap opera "New Home, New Life", nodded emphatically.

- Several times young boys were seen sitting beside the road and asking for donations to rebuild local mosques.

- A frequent view, boys repairing holes along the road and passengers dropping small amounts of money to acknowledge this valuable activity.

- Before taking a turn on top of a hill, our driver prayed silently, as he confessed later on. The danger of landmines has become ingraved in people's mind.

- A sixteen year old village girl who can read and write carries all the weight of her literacy responsibility. The sixteen year old is determined to teach this skill to other women in the village.

- Most of the trucks seen on the way to and from Khost carry firewood. Deforestation causes floods which destroy crops as farmers reported.

- In Khost city, while visiting the bazaar, Taliban voluntarily assisted keeping away curious onlookers who were attracted by the rather odd composure of our visiting group.

- Khost airport with its destroyed 30 or so Russian gunships sitting like science fiction creatures besides the runway is a living museum. It was learned that local authorities decided to preserve this recent token of history despite a great market demand for scrapmetal.

- Electricity is provided by a generator which is turned on during few hours a day and a hot shower is something a traveler starts to dream about after a dusty roadday in Afghanistan. 


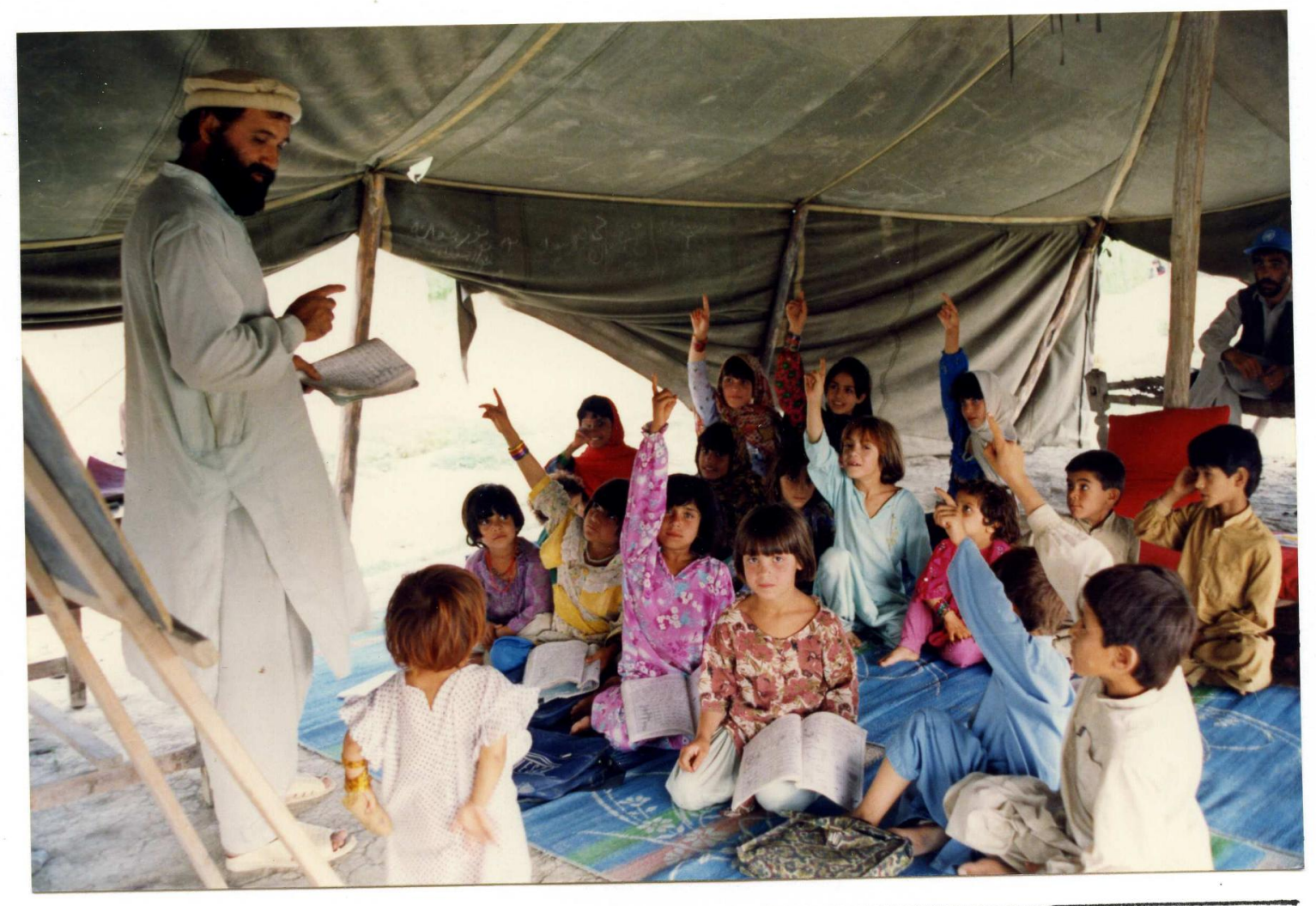

HOMESCHOOL PROJECT, KHOST

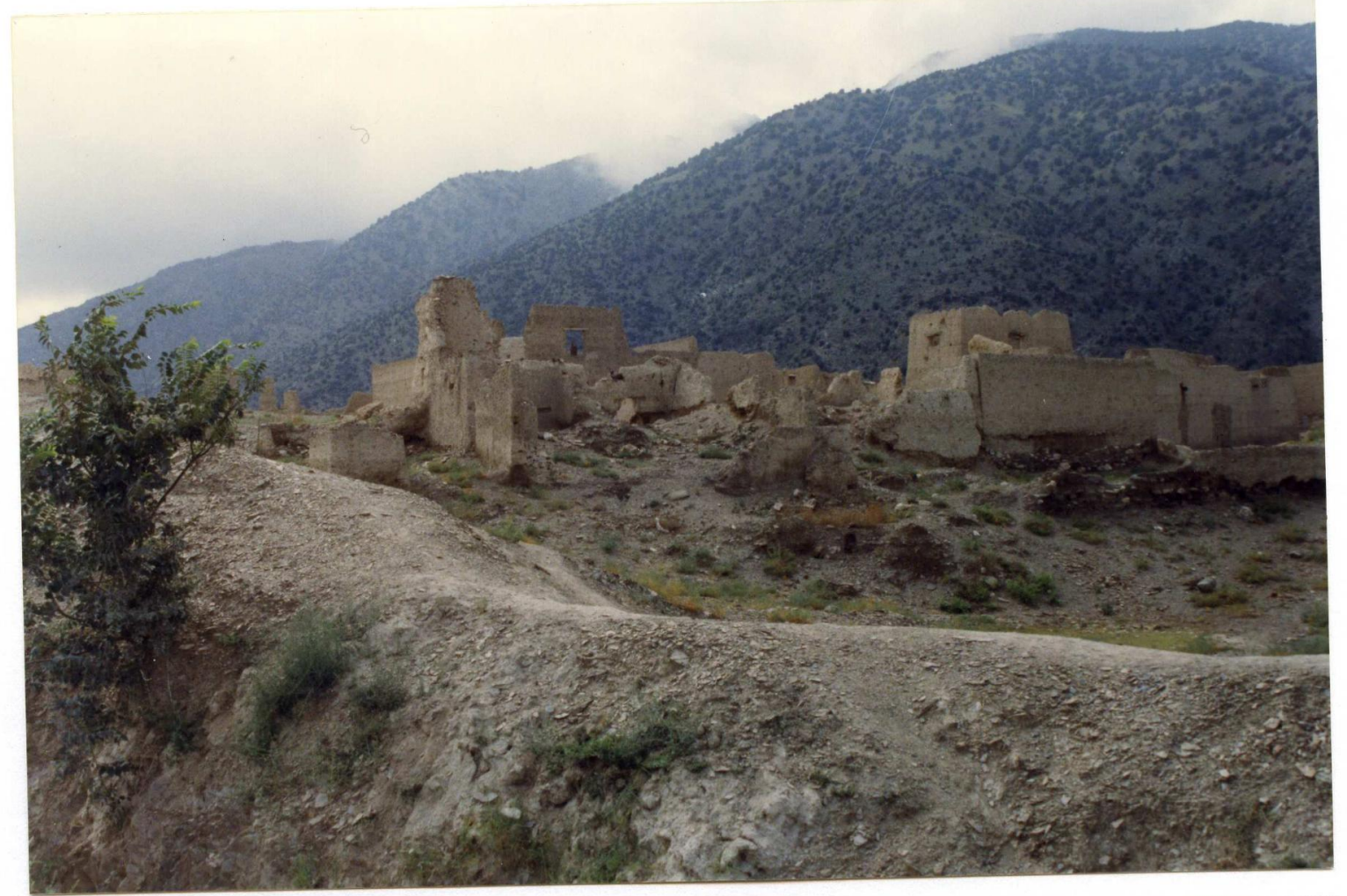

DESTROYED HOME - KHOST AREA 


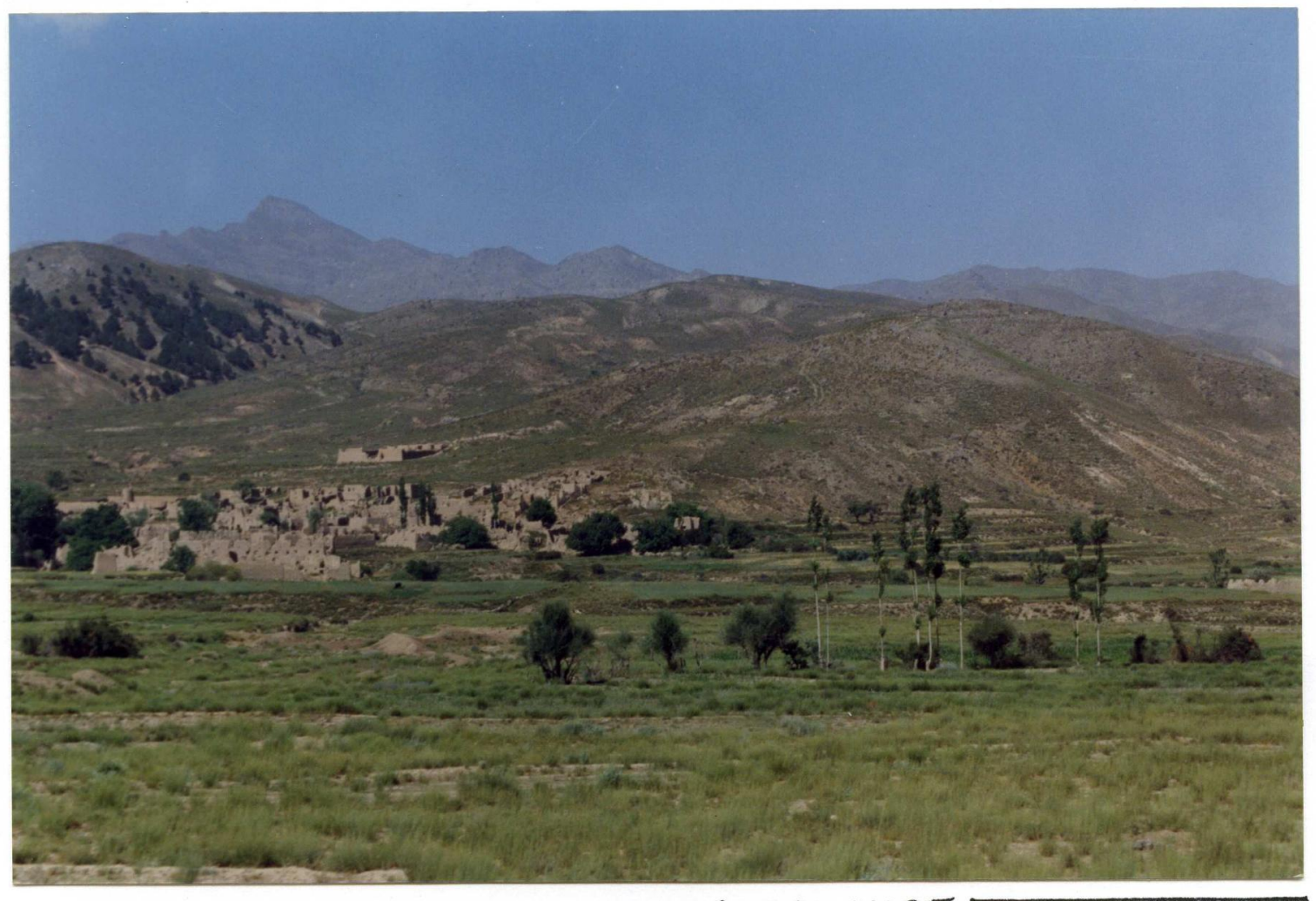

depopulated Villages, paktia province

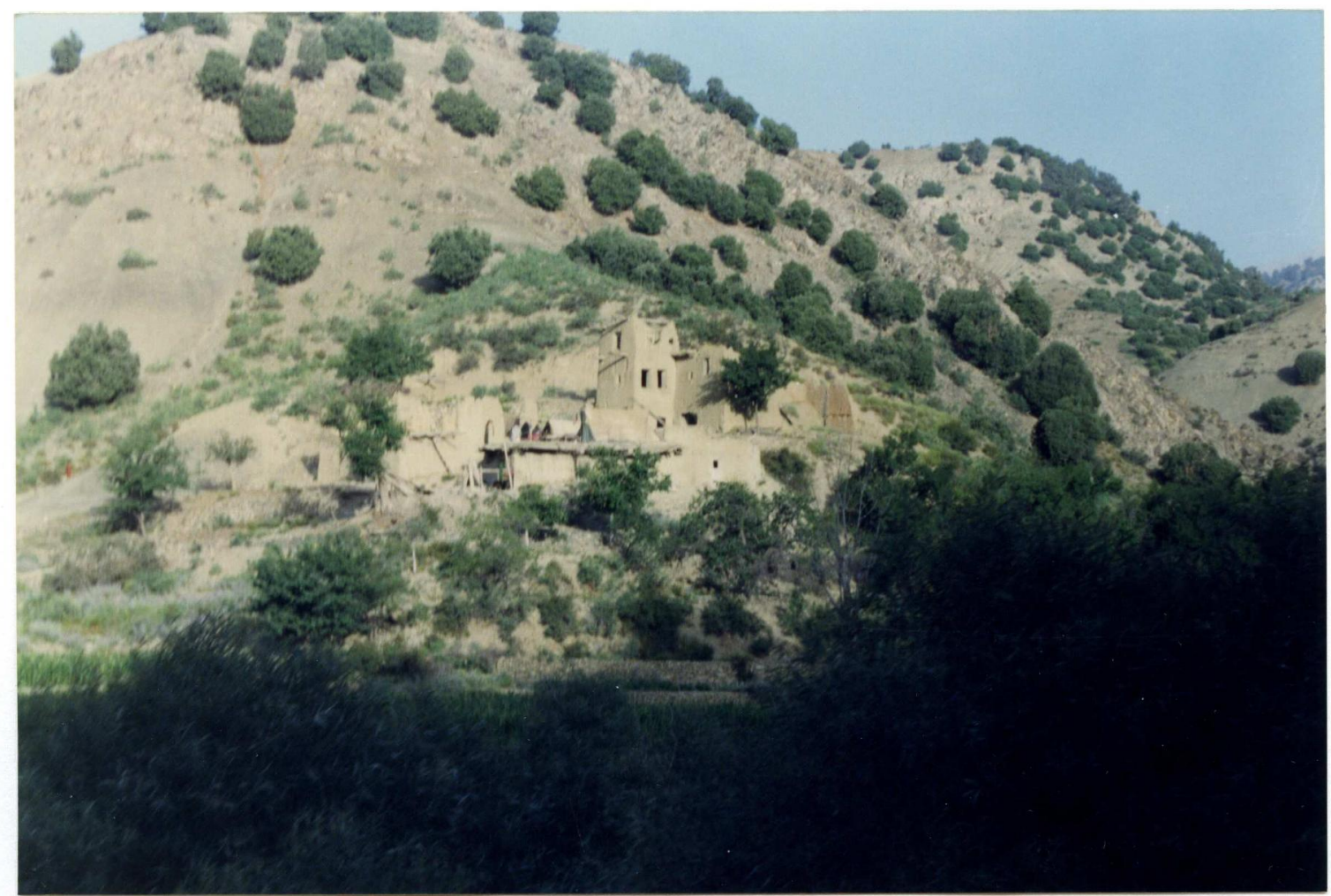

a refugee family pecided to return home, paktia 


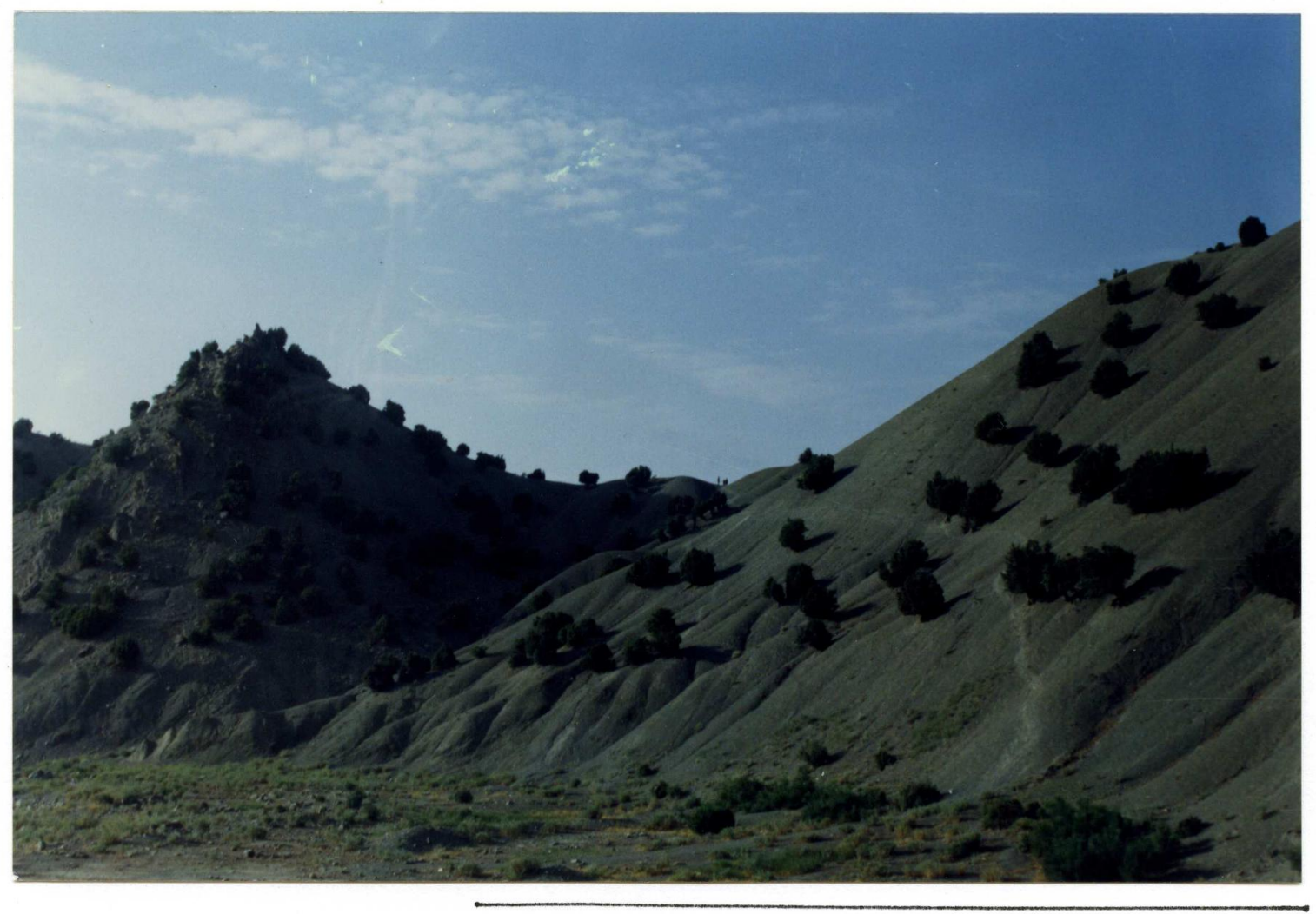

DEFORESTATION...

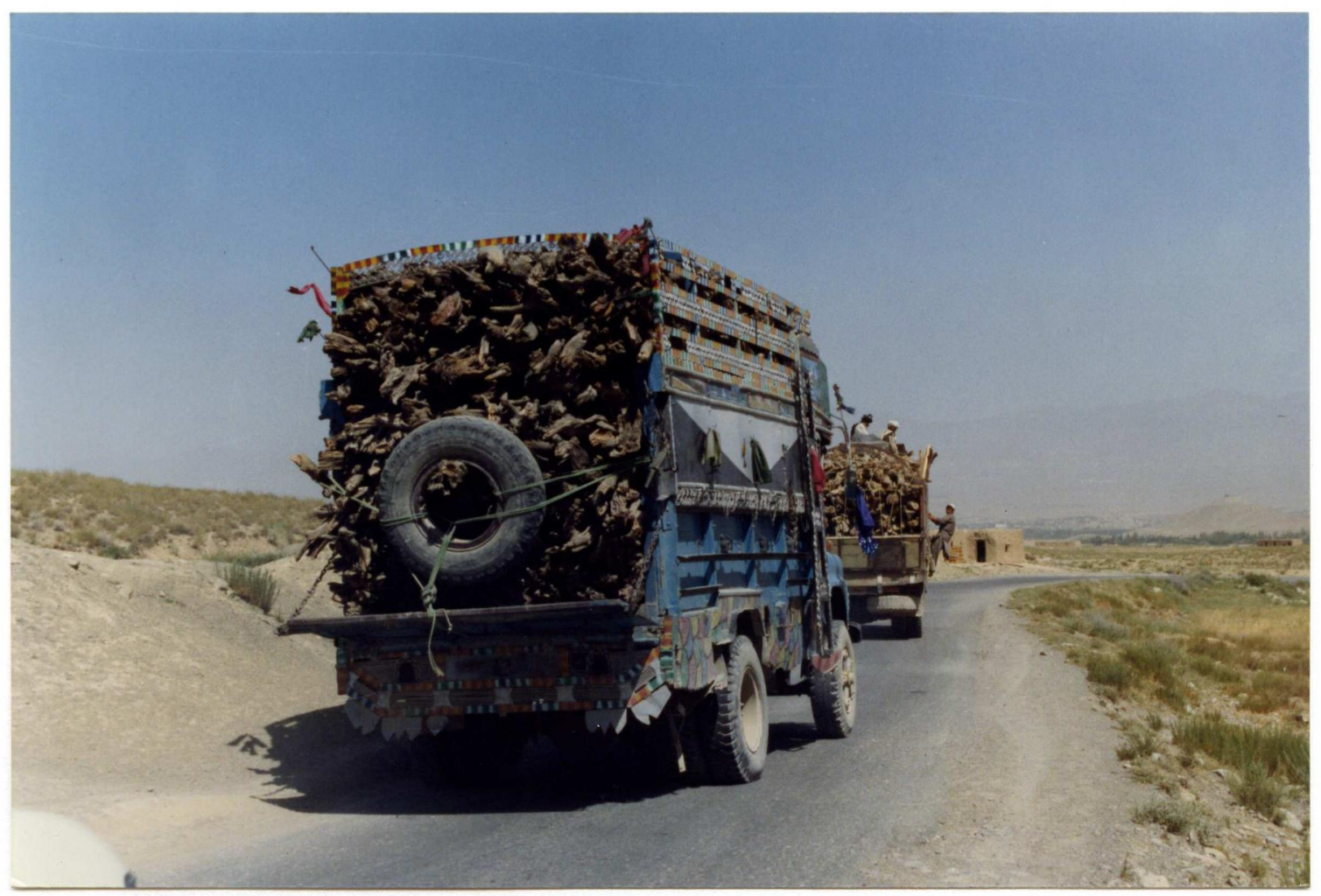

... AND FIREWOOD ONTHE WAY TO THE MARKET, raKTIA 



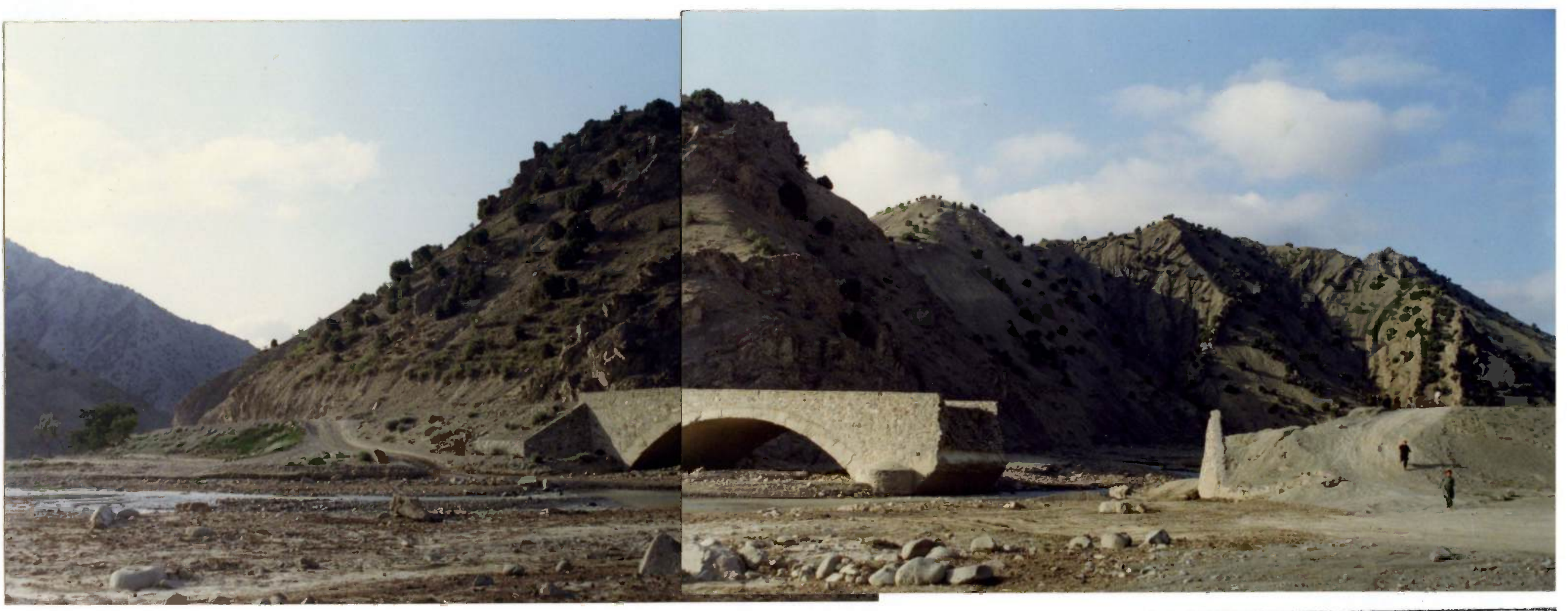

DESTROYED LAKA TIKA BRIDGE ONTHE WAY BETWEEN KHOST \& GARDEZ, PAKTIA 


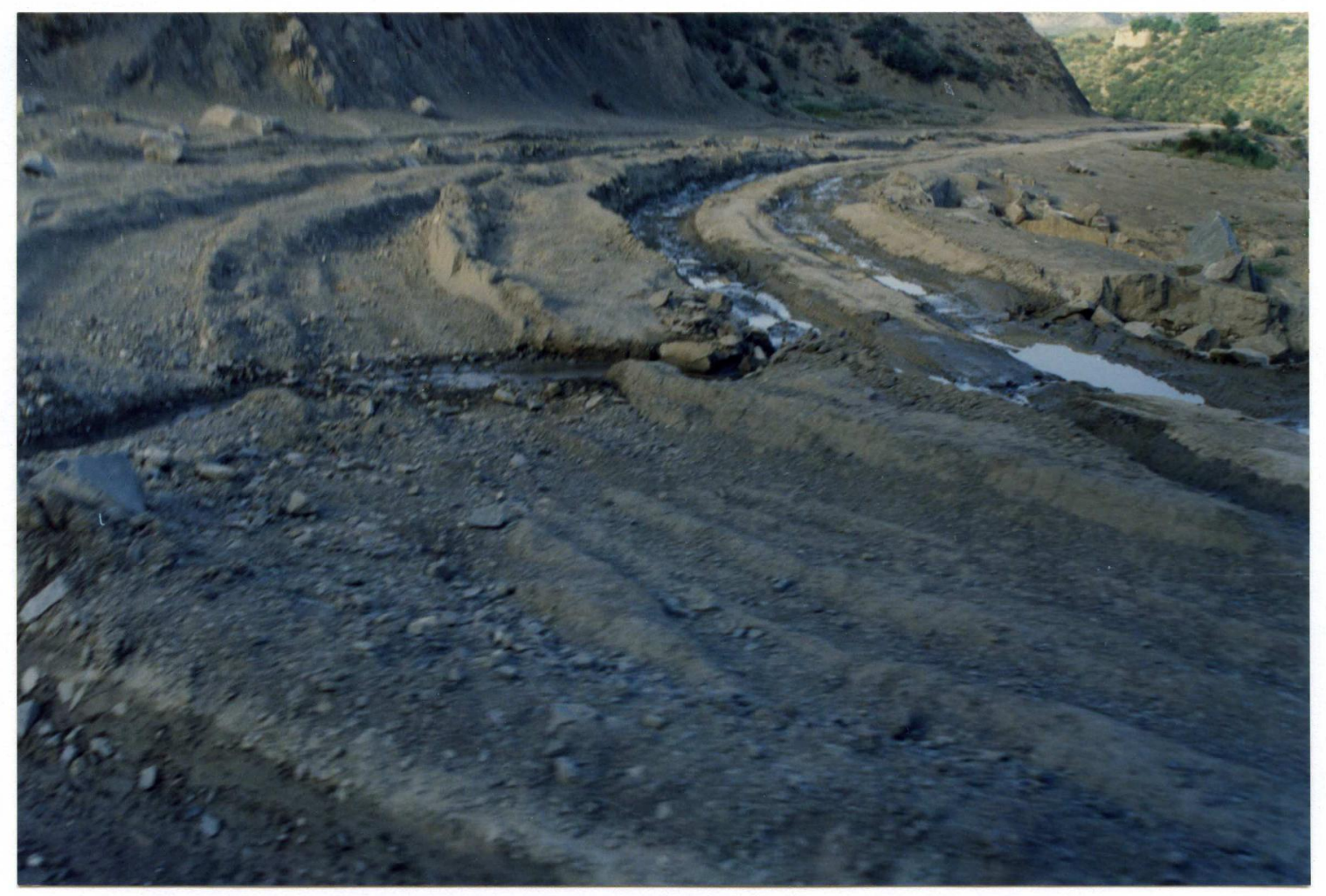

"ROADS", PAKTIA

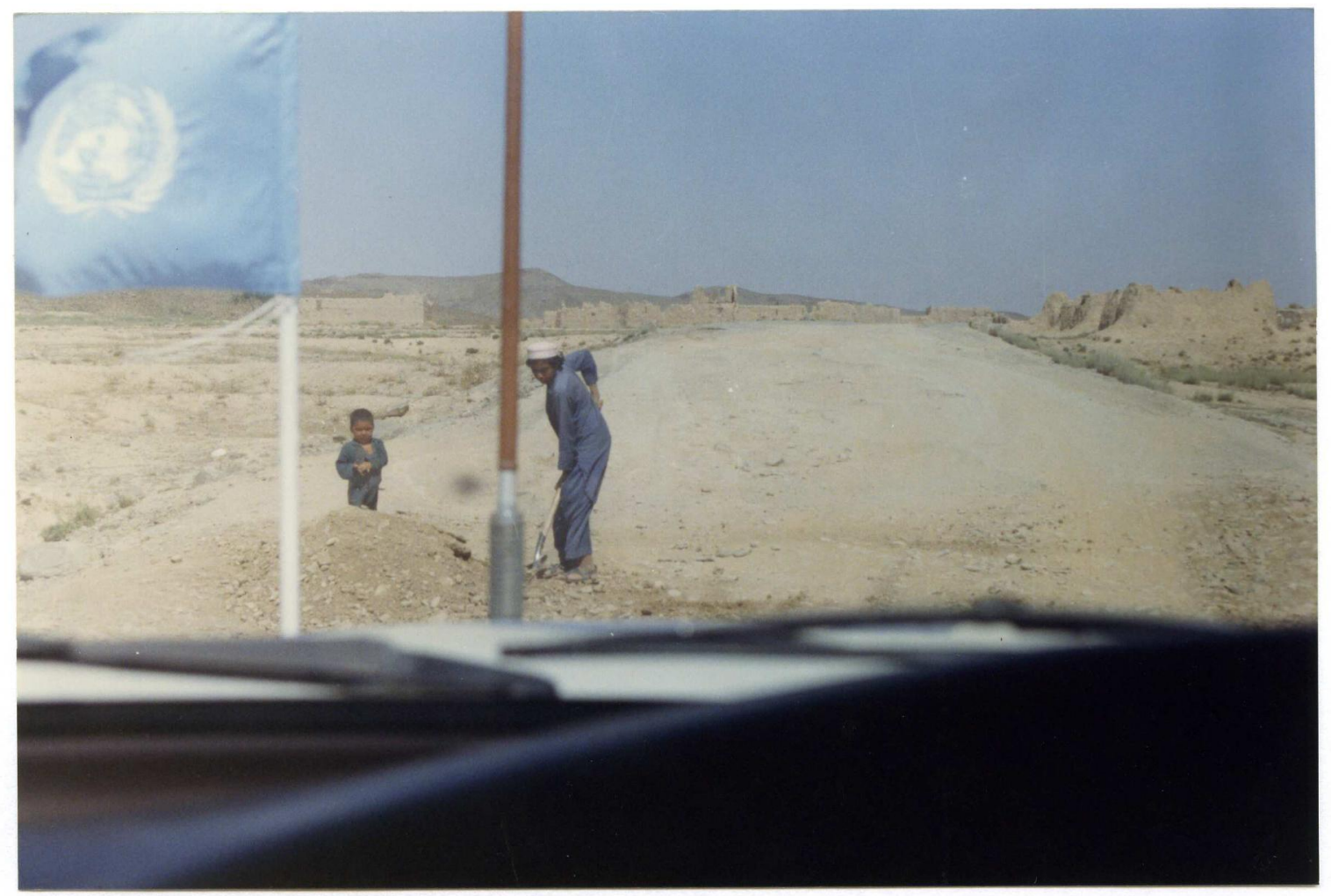

CHILPREN REPAIRING ROADS, PAKTIA 